\title{
The Seventh 'P' in Marketing Mix-The Process: An Empirical Study
}

\author{
Samuel Augustina Lata Jeyaraj* \\ Department of Business Administration, Vivekanandha College of Arts and Sciences for Women, \\ (Autonomous), Thiruchengode - 637303, Tamil Nadu, India; \\ augustinababu@gmail.com
}

\begin{abstract}
The revolution of Indian industry during the last decade has witnessed an accelerating and significant rise in the retail sector. With various prominent modern retail formats that have paved avenue to the large global players to explore large market potential in the Indian economy have in fact given a rich shopping experience to the retail consumers. Indian retail drastically changed its move from traditional market commonly known as an unorganised retail market to modernization of organised retail sector by evolving new ways of retailing. But the scenario of a restless queue of consumers waiting for billing their select items in the organized retail outlets is not uncommon. Hence, the present study exposes the factors determining their opinion on billing process and that of the problems faced in this regard.
\end{abstract}

Keywords: Billing Process, Organised Retail Sector, Retail Outlets

\section{Introduction}

In urban India, families are nuclear rather than joint. Women work force's contribution of income to the family leads them to demand better quality of branded products, expectation of quality services and uniqueness in shopping. Lack of time to the modern generation hinders them to visit shop to shop for purchase. Preference of people to shop in department stores, supermarket and corporate store is increasing as they perceive to purchase their needs under one roof. The emergence of newer, specialized and giant growth of retail formats in semi urban and rural area focuses on experiential aspects of shopping. In organized store, the retailer has to direct the sales personnel to assist the consumer right from the process of selecting the product till the final purchase. The process link must not break in between the purchase and the delivery of products. In traditional retailing the basic aim of the retailer is to sell the goods, there by earn profit but, modern retailing gives attention to deliver the products with good after-sales services. Besides, the process is well designed in blueprint, setting for a sequence of standard actions in the order of service to be implemented.

\section{Review of Literature}

Girish Nair and Harish Nair ${ }^{1}$ exposed the retail service quality determining the customers' overall impression and satisfaction derived from the retail outlet. Rigopoulou et . $\mathrm{al}^{2}$ brought to the fore the factors creating negative perception and decreased customer dissatisfaction towards super markets. Ciavolino and Dahlgaard ${ }^{3}$ measured the quality of service based on both the attributes of the core product and other general attributes that exist in super market. 


\section{Objectives}

- To bring out the demographic profile of the select respondents

- To study the factors influencing the consumer opinion on Billing Process

- To analyse the problems faced by the consumers during the billing process in the organized retail stores.

\section{Area of the Study}

The study is undertaken in Erode district by administering the questionnaire among the consumers of the organised retail outlets viz., department stores, super markets and corporate stores.

\section{Sampling Design}

Convenience sampling method was adopted in the selection of the respondents totaling 1067 from Anthiyur,
Bhavani, Erode, Perundurai, Gobichettipalayam and Sathyamangalam of Erode district, all being consumers making their purchases in the organized retail stores.

\section{Data Collection}

Primary data was obtained from the sample respondents through a well framed questionnaire.

Necessary secondary data were gathered from journals and websites pertaining to retail sector to supplement the primary data.

\section{Demographic Profile of the Respondents}

Table 1 reveals the frequency distribution of the sample respondents in respect of the nine demographic factors.

It can be noted from Table 1 that out of a total sample of 1067 respondents hailing from six taluks, a maximum of $32.99 \%$ of them belong to Erode, a majority of $50.23 \%$ were male; a majority of $70.85 \%$ were married; a maximum of $40.39 \%$ were of the age group of 25-40 years; a majority

Table 1. Demographic profile of the respondents- percentage analysis

\begin{tabular}{|c|c|c|c|}
\hline \multicolumn{2}{|c|}{ Demographic Profile } & Frequency & Percentage \\
\hline \multirow{4}{*}{ Taluk } & Anthiyur & 97 & 9.09 \\
\cline { 2 - 4 } & Bhavani & 198 & 18.56 \\
\cline { 2 - 4 } & Erode & 352 & 32.99 \\
\cline { 2 - 4 } & Gobichettipalayam & 161 & 15.09 \\
\cline { 2 - 4 } & Perundurai & 116 & 10.87 \\
\cline { 2 - 5 } & Sathymanglam & 143 & 13.40 \\
\hline \multirow{5}{*}{ Gender } & Total & $\mathbf{1 0 6 7}$ & $\mathbf{1 0 0 . 0 0}$ \\
& Male & 536 & 50.23 \\
\hline & Female & $\mathbf{1 0 6 7}$ & $\mathbf{1 0 0 . 0 0}$ \\
\hline
\end{tabular}


Table 1 Continued

\begin{tabular}{|c|c|c|c|}
\hline \multirow{2}{*}{ Marital status } & Married & 756 & 70.85 \\
\hline & Unmarried & 311 & 29.15 \\
\hline & Total & 1067 & 100.00 \\
\hline \multirow{5}{*}{ Age } & Less than 25 & 222 & 20.81 \\
\hline & $25-40$ & 431 & 40.39 \\
\hline & $41-60$ & 338 & 31.68 \\
\hline & Above 60 & 76 & 7.12 \\
\hline & Total & 1067 & 100.00 \\
\hline \multirow{5}{*}{ Educational qualification } & School & 163 & 15.28 \\
\hline & Collegiate & 556 & 52.11 \\
\hline & Profession & 264 & 24.74 \\
\hline & Illiterate & 84 & 7.87 \\
\hline & Total & 1067 & 100.00 \\
\hline \multirow{7}{*}{ Status in the society } & Agriculturist & 88 & 8.25 \\
\hline & Business/Profession & 182 & 17.06 \\
\hline & Private Employee & 170 & 15.93 \\
\hline & Govt. Employee & 365 & 34.21 \\
\hline & Housewife & 105 & 9.84 \\
\hline & Retired & 68 & 6.37 \\
\hline & Student & 89 & 8.34 \\
\hline & Total & 1067 & 100.00 \\
\hline
\end{tabular}


Table 1 Continued

\begin{tabular}{|c|c|c|c|}
\hline \multirow{4}{*}{ Monthly income } & Rs.5,000-Rs.10,000 & 245 & 22.96 \\
\hline & Rs.10,001-Rs.20,000 & 387 & 36.27 \\
\hline & Rs.20,001-Rs.30,000 & 294 & 27.55 \\
\hline & Above Rs.30,000 & 141 & 13.21 \\
\hline & Total & 1067 & 100.00 \\
\hline \multirow{3}{*}{ Type of family } & Nuclear & 719 & 67.39 \\
\hline & Joint & 348 & 32.61 \\
\hline & Total & 1067 & 100.00 \\
\hline \multirow{5}{*}{ Family size } & Three Members & 49 & 4.59 \\
\hline & Four Members & 218 & 20.43 \\
\hline & Five Members & 504 & 47.24 \\
\hline & Above 5 Members & 296 & 27.74 \\
\hline & Total & 1067 & 100.00 \\
\hline
\end{tabular}

Sources: Primary Data

of $52.11 \%$ were college educated; a maximum of $34.21 \%$ were government employees; a maximum of $36.27 \%$ were earning a monthly income ranging from Rs.10,001/- to 20,000/-; a majority of $67.39 \%$ belonged to nuclear family; and a maximum of $47.24 \%$ have a family size comprising five members.

\section{Consumer Opinion on Billing Process}

The opinion of the consumers on the billing process is analysed by applying the chi-square test and the result is given in Table 2.
Ho: There is no significant relationship between demographic profile of the respondents and their opinion on the billing process as consumers.

It is noted from Table 2 that the $\mathrm{p}$ value is less than 0.05 in case of 'status in the society' (0.003) and 'type of family' (0.003), which stand significant at $1 \%$ level. Hence, it is concluded that there is a significant relationship between the demographic factors- 'status in the society' and 'type of family' and that of the opinion of the consumers on billing process.

Whereas, there is no significant relationship between the other demographic factors, namely taluk, gender, marital status, age, educational qualification, monthly income 
Table 2. Demographic profile and consumer opinion on billing process - Chi-Square Test

\begin{tabular}{|c|c|c|c|c|}
\hline $\begin{array}{c}\text { Demographic Profile of the } \\
\text { respondents }\end{array}$ & Chi-square & DF & 'p' value & Sig. \\
\hline Taluk & 12.21 & 10 & 0.271 & Not Significant \\
\hline Gender & 4.42 & 2 & 0.110 & Not Significant \\
\hline Marital status & 2.40 & 2 & 0.301 & Not Significant \\
\hline Age & 5.89 & 6 & 0.435 & Not Significant \\
\hline Educational qualification & 2.38 & 6 & 0.882 & Highly Significant \\
\hline Status inthe society & 29.90 & 12 & $0.003^{* *}$ & Not Significant \\
\hline Monthly income & 2.19 & 6 & 0.901 & 0.102 \\
\hline Type of family & 11.57 & 2 & Highly Significant \\
\hline Family size & 10.60 & 6 & Not Significant \\
\hline
\end{tabular}

** Significant at $1 \%$

and family size with that of the opinion of the consumers on the billing process.

\section{Problems Faced in the Billing Process}

The time lag between selection and billing process creates a chaos among the consumers when the queue is large.
Their increasing waiting time leads to discomfort and this may give the chance for cancelling the purchase. Hence, the problems faced by the sample respondents during their purchases in the organised retail outlets are presented in Table 3.

The results of Garrett Ranking analysis as shown in Table 3 depicts that among the four problems, the problem of 'untrained computer operators' has ranked first with a

Table 3. Problems faced in the billing process - Garrett ranking

\begin{tabular}{|c|c|c|c|}
\hline Problems & Total score & Garrett score & Garrett Rank \\
\hline Favoritism is followed & 53986 & 50.59 & III \\
\hline Untrained computer operators & 56642 & 53.08 & I II \\
\hline Number of counters are less & 55483 & 51.99 & IV \\
\hline Improper swiping of plastic cards & 49423 & 46.31 & . \\
\hline
\end{tabular}


Garrett score of 53.08 points, 'number of counters are less' has ranked second with a Garrett score of 51.99 points, 'favoritism is followed' has ranked third with a Garrett score of 50.59 points, 'improper swiping of plastic cards' has ranked fourth with a Garrett score of 46.31 points. Thus, it can be inferred that the problem of 'untrained computer operators' is the top most problem faced by the consumers when shopping in the organized retail stores.

\section{Key Findings}

The Chi-square analysis has revealed that the 'status in the society' and the 'type of family' are the two demographic factors which influence the consumer opinion on the billing process.

The top most problem faced by the respondents in the organised retail stores during the process of purchase as revealed by Garrett ranking analysis is 'Untrained computer operators.

\section{Suggestion}

It is suggested that more number of trained computer operators must be employed for billing, so that the consumers save the time in billing and the waiting time in queue, which promotes to visit the stores again and again for further purchases.

\section{Conclusion}

The retailer should facilitate more number of billing counters with well experienced computer operators who can do their job expeditiously. Although the consumer enjoys the shopping, the frustration emerges when there is a delay in the process of completion. Adequate steps have to be taken by the retailers to ensure that the consumers go happily when they move out of the shop so as to make them visit again and again.

\section{References}

1. Nair G, Nair H. An analysis on consumer perception towards service quality variety in selected organised retail outlets. International Journal of Management and Social Sciences Research. 2013; 2(1):56-61.

2. Rigopoulou et al. Shopping orientation defined segments based on store- choice criteria and satisfaction, An empirical investigation. Journal of Marketing Management. 2008; 24(9):979-95. https://doi.org/10.1362/026725708X382000

3. Ciavolino, Dahlgard. Customer satisfaction towards retailers, ICA, NÄRA and Coop Forum; 2007. p. 1-50.

4. Newman AJ, Cullen P. Retailing environment and operation, locating the store in the retail environment. 2008. p. 227.

5. Mishra A, Gupta R. Customer service in retailing. First Edition. Biztantra; 2009.

6. Kurtz DL, Boone LE. Principles of marketing. 12th Edition. Thomson South-Western; 2006.

7. Lusch D. Retail management. 5th ed. Cengage Learning India Pvt Ltd; 2011. PMCid:PMC3388796

8. Gupta SL, Ratna VV. Advertising sales Promotion management. First Edition. New Delhi: Sultan Chand; 2004 . 